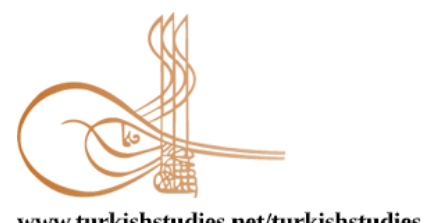

www.turkishstudies.net/turkishstudies
Turkish Studies

eISSN: $1308-2140$

Research Article / Araştırma Makalesi

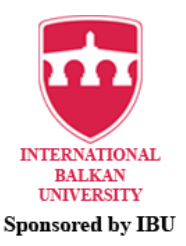

Sponsored by IBU

\title{
Kant Felsefesinde Tanrı ve Ahlak İliş̧kisi
}

God and Moral Relationship in Kant's Philosophy

\begin{abstract}
Ahmet Kavlak*
Abstract: Kant's ethics, as in his philosophy of knowledge, aims to be a constative ethics that is tried to be built on apriori foundations. The source of ethics consists of judgments, which are necessarily derived from the concept of reason and the "intelligent being". The most important of these judgments is the 'moral law' that applies to every intelligent entity. In order to show that man is a moral being, Kant initially suggests three postulates in order to base the fact that man can act independently of nature causality. These are the concepts of freedom, immortality of the soul, and God. However, it is not enough for human freedom to be able to act outside of nature causality. In order to be free, it is also necessary to "ask" in accordance with moral law. Kant's conception of God is a passive one, as in Christianity. In this sense, it is closer to deism. However, there is a need for God in order for these concepts, such as happiness and virtue, to come together by chance, to achieve the "highest good". And this means an active understanding of God. Kant objects to ontological and cosmological evidence trying to prove God's existence. He suggests that God's existence cannot be proved, but God is needed to act morally, so he moots an nonassertive evidence called moral proof. The nature of the existence of God and immortality of the soul, which Kant, who bases the moral mobility of people with the concept of freedom, resorted to eliminate the despair that hinders action according to moral law, is also unknown. Kant states that as the source of morality, it must be reason, not God, but God is needed to achieve the highest good. Kant ethics has become a secular-speaking theist way of thinking in a sense.
\end{abstract}

Structured abstract: The purpose of the philosophy of morality is to determine the universal right and wrong - if there is any - to provide the criterion of why a person should behave accordingly, to analyze the spiritual and physical structure of the human in terms of happiness and virtue or the best good, to set up rules or to determine existing rules, if any, to show compelling or suggestive reasons for why people should follow these rules. There is no doubt that there is a difference between how one should behave and how $\mathrm{s} / \mathrm{he}$ behaves. Unlike morality whose concepts are good and bad, it can be said that ethics, whose concepts are true and false, examines ideal human-specific behavior. This "ideal person" means the person who is able to demonstrate the ability to follow the rules of ethics set by his/her own mind.

"Kant's Moral Philosophy" is a moral philosophy based on non-religious foundations. However, enlightenment philosophers accepted Christian revelation, including Kant, others except Hume defended it. Kant's moral philosophy is based on reason. The starting point of this philosophy is the presupposition that man is free and therefore a moral being.

\footnotetext{
${ }^{*}$ Dr. Öğr. Üyesi, Ankara Yıldırım Beyazıt Üniversitesi, İnsan ve Toplum Bilimleri Fakültesi, Felsefe Bölümü Asst. Prof. Dr., Ankara Ylldırım Beyazıt University, Faculty of Human and Social Science, Philosophy Department ORCID 0000-0002-4419-9440

ahmetkavlak@gmail.com

Cite as/ Atıf: Kavlak, A. (2020). Kant felsefesinde Tanrı ve ahlak ilişkisi. Turkish Studies, 15(3), 2141-2156. https://dx.doi.org/10.29228/TurkishStudies.43580

Received/Geliş: 14 May/Mayıs 2020

Accepted/Kabul: 20 June/Haziran 2020

Copyright (C) MDE, Turkey

Checked by plagiarism software

Published/Yayın: 25 June/Haziran 2020

CC BY-NC 4.0
} 
The definition of human, his duty, whether he is free, whether there is a universal moral law, whether values can be deducted from the facts, what will be the criterion in determining good and evil, the place of mind, religion and God in the concept of morality, what is the highest good, whether it can be reached, what kind of method should be followed if it is to be reached, what is driving the person to comply with the truth and not to make the wrong are what the moral philosophy has been trying to find answers, Kant's moral philosophy also tries to respond to these issues. How Kant answers these questions will be tried to be shown in the main topics of his own moral philosophy.

Kant, who is looking for the apriori roots of knowledge, is looking for apriori roots of morality as he aims to reach a definite moral knowledge in morality. If there is knowledge of apriori in the field of morality, which Kant primarily moves from the idea that it exists, then it can be a scientific moral doctrine. Considering that reliance on apriori foundations is the first step to universality, Kant believes that these apriori bases are in mind, even in the minds of ordinary people.

According to Kant, man belongs to both the world of causality and the world of freedom. Freedom is of two kinds; to act separately from causality of nature (negative freedom), to determine this action according to moral law (positive freedom). Since something cannot exist and disappear, nor can it be what it is and is not, the mandatory consequence of Kant's human definition is the condition that a person's soul, which is outside of causality, as in both Plato and Descartes, actually exists.

Kant shows the nature of the mind with the intention of basing that man is not created only for happiness. Mind, which animals do not possess, does not prevent them from living comfortably. So this extra mind of man should serve a different purpose than happiness, which means satisfying needs. Man was created for something other than happiness. That is, the mind makes it hear a voice from another world; moral law, moral imperative. The fact that man can do something outside the mechanism of nature makes it possible for him to comply with moral law.

This view of Kant is parallel to the content of Hobbes with the word "Man is the wolf of man". Because the reason for the conflict is the individual feeling of pleasure, which cannot be restrained in the human, and the purpose of the pleasure is happiness. Kant emphasizes that if happiness is the goal, universality cannot be achieved and individual judgments will continue.

We can understand whether our actions comply with moral law by not turning it into a provision that eliminates itself in the event that the action is universalized provided that the person is accepted as the purpose The task is therefore to act according to the maxim we may want to be a general applicable law. The concept of task tells us about the supreme good. It is a virtue to comply with the best and to be worthy of happiness. However, one cannot afford to combine virtue and happiness. The remedy is the immortality of the soul and the postulates of God.

This is one of the dilemmas in Kant's philosophy. If God has an interference with man (such as establishing the bond of virtue and happiness) and the universe, why not measure Him when determining right and wrong? If God does not interfere, then what is the point of accepting Him as a postulate? The nature of Kant's God is unknown. Even if Kant himself had a theistic understanding, his God is neither the God of the Theists nor the God of the Deists, the nature of God is unknown. Although His superior ability to do supreme good requires Him to be active, Kant's God is passive, as in Christianity. Although God's acceptance brought up the possibility of revelation, Kant opposed theological morality. Kant established his moral philosophy by thinking of man as a mind entity, and he did not take into account that situations where the order of the mind is not followed are not contrary to reason. He divided the human into two as a phenomenon and a numen, and prepared the ground for morality, but the idea of morality was created by considering only the numen side of the human being.

The views of Kant are in line with the views of the Mu'tazila sect in the Islamic world, which claims that the good and evil, beauty and ugliness exist independently on their own. As the Mu'tazila sect considers the importance of revelation as an authority, a compelling point to the truths that the mind finds, Kant considers the importance of religions in regarding of helping morality, at the point of giving hope, that believing helps human beings, because "he clearly states that disbelief will lead a moral breakdown."

As a result, Kant fell into the position of defending both the moral values are determined by man and the principles of morality are universal, and he accepted God as a postulate to get rid of the contradiction. Since the philosophy of morality has made man despair, he accepted God, and was subjected to the 
accusation that he reached God's existence out of desire and need. Kant appeared as a theologian using a secular language. Among the philosophers who can be considered as followers of Kant, especially in the way that Hegel established to put Christianity on the grounds of mind, there is the analysis of the practical effects of Kant's passive god understanding and the concepts of "numen" in history.

The strongest feeling in man is the feeling of not disappearing. With the referral of this emotion, he researches and tries to find solutions. He looks for clues that will eliminate the danger of leaving his existence. Taking action in accordance with these tips is due to a sense of protection. Therefore, the measure in right and wrong is, in contrast to Kant, whether man is suitable for his longing for eternity. When eternity is not accepted, it is inevitably at the point of being in the interest of the present. Kant himself admits that mind is limited. The task of man, then, is not to produce theories that command with limited intelligence, but to investigate what the universe and man are. Because it is obvious that the words that can be said without knowing the nature of the universe and man cannot be accurate. The mind is not the authority, but the one that detects the authority. It is a discoverer, not an inventor.

Keywords: the philosophy of religion, moral law, the highest good, freedom, passive God, immortality of the soul

Öz: Kant etiği, onun bilgi felsefesinde olduğu gibi, apriori temeller üzerine kurulmaya çalışılan saptamacı bir etik olma amacındadır. Etiğin kaynağı akıl ve "akıl sahibi varlık" olmak kavramından zorunlu olarak türetilen yargılardan ibarettir. Bu yargıların en önemlisi akıl sahibi her varlık için geçerli olan 'ahlak yasası'dır. Kant insanın ahlaki bir varlık olduğunu göstermek için başlangıçta insanın doğa nedenselliğinden bağımsız olarak eyleyebildiğini temellendirmek amacıyla üç postulat koymaktadır. Bunlar; özgürlük, ruhun ölümsüzlüğü ve Tanrı kavramlarıdır. Ancak insanın doğa nedenselliğinin dışında eyleyebiliyor olması özgürlüğü için yeterli değildir. Özgür olabilmek için ahlak yasasına uygun "isteme" de gerekmektedir. Kant'ın Tanrı anlayışı Hıristiyanlıkta olduğu gibi pasif Tanrı anlayışıdır. Bu anlamda deizme daha yakındır. Ancak 'en yüksek iyi'nin gerçekleşmesi, mutluluk ve erdem gibi birbiriyle tesadüfen bir araya gelen bu kavramların bir araya gelebilmesi için Tanrıya gereksinim vardır. Bu da aktif Tanrı anlayış̧ı demektir. Kant Tanrının varlığını ispat etmeye çalışan ontolojik ve kozmolojik delillere itiraz eder. Tanrının varlığının ispat edilemeyeceğini, ancak ahlaki davranabilmek için Tanrıya ihtiyaç olduğunu, bu nedenle ahlak kanıtı denilen iddiasız bir delili öne sürer. Özgürlük kavramı ile insanın ahlaki eyleyebilme yeteneğini temellendiren Kant'ın, ahlak yasasına uygun eylemeye engel olan ümitsizliği ortadan kaldırmak için başvurduğu Tanrının varlığı ve ruhun ölümsüzlüğ̈̈ kavramlarının da mahiyeti meçhuldür. Kant ahlakın kaynağı olarak Tanrının değil aklın olması gerektiğini, fakat en yüksek iyinin gerçekleşmesi için de Tanrıya ihtiyaç olduğunu belirtir. Kant etiği bir anlamda seküler konuşan bir teist düşünce ifadesi şekline dönüşmüştür.

Anahtar kelimeler: din felsefesi, ahlak yasası, en yüksek iyi, özgürlük, pasif Tanrı, ruhun ölümsüzlüğü

\section{Ahlak ve Ahlak Felsefesi}

Ahlak kelimesi: Arapça huy, tabiat ve haslet anlamlarına gelen "hulk" kelimesinin çoğuludur. Ahlak insanın davranış tarzını, tutumunu ve tavrını, toplumda iyi sayılan davranış kurallarını ifade etmek için kullanılır. Felsefede inceleme konusu olan ahlak, "genellikle insanların kendisine göre yaşadıkları bir ilkeler topluluğu, bir kurallar toplamı anlamına gelir"(Cevizci, 1996:94). Ahlak felsefesi ise "ahlaki olanın temellerini ve özünü insanın davranışları ile ilgili problemleri iyinin ne olduğunu, insanın neyi yapabileceğini soruşturan felsefedir" (Bolay, 1996:5). Ahlak felsefesinde, iyi ve kötü kavramlarının ne olduğu gibi konular bulunduğundan, ahlaktan farklı olarak (ahlak felsefesi) "son çözümde değerlendirmeye çalışan felsefi soruşturma dalıdır" (Cevizci, 1996:4). Ahlak felsefesinin görevi davranışları tasvir etmek, birbirleri ile olan ilgilerini, hangi davranışların toplumda var olduğunu bulmak değil; onları değerlendirmek, davranışlar 
hakkında iyi ya da kötü hükmünü vermektir. Diğer toplumsal bilimlerden farklı olarak, ahlak felsefesi kural koyucudur. ${ }^{1}$

Ahlak felsefesinin amac1; evrensel doğru ve yanlışı -eğer varsa- tespit etmek, insanın niçin, neye göre davranması gerektiğindeki ölçütü vermek, insanın ruhi ve bedeni yapısının mutluluk ve fazilet ya da en üstün iyi açısından tahlilini yapmak, kurallar koymak ya da varsa mevcut kuralları tespit etmek, bu kurallara insanın niçin uyması gerektiği konusunda zorlayıcı, veya tavsiye edici sebepleri göstermektir. İnsanın nasıl davranması gerektiği ile nasıl davrandığı arasında farklılık bulunduğundan şüphe edilemez. Yukarıda geçtiği gibi kavramları iyi ve kötü olan ahlaktan farklı olarak, kavramları doğru ve yanlıș olan "etik'in ideal insana özgü davranıșı incelediği söylenmelidir" (Reichenbach, 1993:50). Bu 'ideal'den kasıt kendi aklının koyduğu ahlak kurallarına uyma becerisini gösterebilmiş olan demektir.

Ahlak teorileri, din ile temellendirilmeleri veya din dışı temellere dayanmaları, şekliyle ikiye ayrılırlar. İnceleyeceğimiz, "Kant'ın Ahlak Felsefesi", din dişı temellere dayanan bir ahlak felsefesidir. Ancak "aydınlanma filozofları, Kant da dahil, Hristiyan vahyini ${ }^{2}$ kabul etmişler, Hume hariç diğerleri onu savunmuşlardır" (Bolay, 1996:27). Kant'ın ahlak felsefesi akı1 ile temellendirilmiştir. Bu felsefenin başlangıç noktası insanın özgür dolayısıyla da ahlaki varlık olduğu ön kabulüdür.

İnsanın tanımı, görevi, özgür olup olmadığı, evrensel bir ahlak kanunun bulunup bulunmadığı, olgulardan değerlerin çıkarılıp çıkarılamayacağı, iyinin ve kötünün seçilmesinde ölçütün ne olacağı, aklın, dinin ve Tanrı'nın ahlak kavramındaki yeri, en yüksek iyinin ne olduğu, ona ulaşılıp ulaşılamayacağı, ulaşılacaksa nasıl bir metot takip edilmesi gerektiği, doğruya uymak ve yanlışı yapmamakta insanı neyin sevk edici olduğu ahlak felsefesinin cevap bulmaya çalıştığ konular olduğundan, Kant'ın ahlak felsefesi de bu mevzulara cevap vermeye çalışmaktadır. Bu sorulara Kant'ın nasıl cevap verdiği, kendi ahlak felsefesinin ana başlıkları içinde gösterilmeye çalış1lacaktır.

\section{Kant'In Ahlak Felsefesi}

'Saf Aklın Kritiği'nde, bilginin apriori köklerini arayan Kant, bilginin apriori köklerini göstermekle, kesinliği yakalamış olma iddiasındaydı. Ahlakta da, kesin olan bir ahlak bilgisine varmayı hedeflediği için, ahlakın da apriori köklerini aramaktadır. Kökü apriori temellere dayanan her fikrin evrensel olduğu düşüncesinden hareket eden Kant, ahlak alanında da böyle temellerin varlığını göstermek gayretindedir. Eğer ahlak alanında apriori bilgi varsa, ki öncelikle Kant var olduğu noktasından hareket eder, o zaman bilim niteliğinde bir ahlak öğretisi olabilir. "Bilgi" apriori olmasa idi düzenli bir doğa tablosu yerine gelişigüzel tasarımlar olurdu. Bunun gibi ahlak da gelişi güzel tasarımlara bırakılırsa, tümel geçerliği olan bir ahlak kurulamaz.

Apriori temellere dayanmanın, evrenselliğe ilk adım olduğunu düşünen Kant, bu apriori temellerin akılda, hatta sıradan insanların aklında bile bulunduğu kanaatindedir;

"Bütün ahlak kavramlarının yeri ve kaynă̆ tamamen apriori olarak akılda bulunur; hem de en yüksek derecede kurgusal olan akılda olduğu kadar sıradan insan aklinda da.. (Kant, 1995:27)

\footnotetext{
${ }^{1}$ Kavramları iyi ve kötü olan ahlak ile kavramları doğru ve yanlış olan etik arasında, kural koyucu (normatif)(*) ve tespit edici (anormatif) mahiyet farkı düşünülür. Bu anlamda Aristoteles'in etiği ile Kant’ın etiği kural koyucu değil, saptayıc1, anormatif ve içeriksiz yani sadece çerçevesi belirlenmiş bir anlayışa sahiptir. Fakat sonuçta bu düşünceler hangi tarzda olursa olsun ahlak felsefesidir.

(*) Felsefede normatif kavramıyla ifade edilen, bir otorite açısından iyi ve kötünün kabul edilmesidir. Diğer disiplinlerde olduğu gibi ahlaki değerlere dayalı olarak herhangi bir şeye bağl1lı̆̆ ifade etmez (Uludağ, 2019: 2043-2056).

${ }^{2}$ Hıristiyan vahyini kabul etmenin temel kritiği sadece dindarlık değil, aynı zamanda pasif tanrı anlayışıdır.
} 
Böylece Kant bütün insanları içine alan bir ahlak kanununun dayanabileceği ortak kökü, ahlak kavramlarının apriori olarak her akıllı varlıkta bulunması olarak tarif etmiştir. Evrensellik de, hiç şüphesiz, Kant'a göre; "deneysel, bundan dolay1 da sırf rastlantısal olan bilgilerden çıkarılamaz. (Kant, 1995:27) Tecrübeden gelenler, evrenselliğin kaynağı olamayacağı için, evrenselliğin kaynağının apriori bilgiler taşıyan akılda olması gerekmektedir.

\section{1-Olgu - Değer İlişkisi}

Felsefede olgu, "gerçekliğì" herkes için aynı olan şey anlamını ifade eder. Olgu "gerçek olan, gerçekleşmiş olan, düşünceden bağımsız var olan, gerçekliği inkar götürmez ve kesin olan" (Bolay, 1996:304), zaman ve mekan ile kayıtlı olan şey demektir. Değer ise "olgular ve nesneler hakkında ihtiyaç ve ideallere göre verilen yargıyı ifade eder. Değerde inanç ön plandadır" (Bolay, 1996:82). Değerde yargıda bulunan insan olduğu için, bu yargının sübjektif olması kaçınılmazdır. Ancak yalnızca bir nesne veya olgu hakkında verilen bir hüküm ve yarg1 olmadığından, herkes tarafından kabul edilebilir bir mahiyet taşıması, tekrar edilebilmesi ve zaman-mekan üstü bir vasıf taşıması, zaman-mekan üstü bir kaynağa dayanarak kalıcı olabilmesi gibi özellikleri vardır. "Değer şuura göre aşkın bir varlık, değerlendirme ise bu aşkın varlığın tespitidir” (Kılıç, 1996:301).

Olgu'dan değerin çıkarılamayacağı felsefe dünyasında yaygın kanaattir. Kant da aynı görüştedir. Zaten ahlakın temelini apriori olarak insan aklında araması, ki Kant apriori kavramların herkes için aynı olduğu fikrindedir, bu görüşün neticesidir. Deneyin nesnelerinden evrensel kanun çıkarılamayacağı savunan Kant ${ }^{4}$, bu görüşünü "Saf Aklın Kritiği”nde temellendirmiştir. Ahlak kanununun da, yani evrensel doğrular ve yanlışların da, ancak akıldaki apriori kavramlardan çıkabileceğini savunur. Ancak Kant'ın bu noktadaki görüşleri çok kesinlik iddiası taşıyor gibi görünmesine rağmen, ön kabullerin ağırlığının kendisi de farkındadır. ${ }^{5}$ İleride bahsedileceği gibi, Kant'ın postulatlarından olan insanın mutlak özgürlüğü ve insan istemesinin otonomluğu, olgudeğer ilişkisinde, değeri koyanın insan olmasını gerekli kılar; "istemenin otonomluğu prensibi ${ }^{6}$ gereği, değerleri koyan insandır” (Kılıç, 1993:72).

Evrensellik konusunu zorunluluk takip eder. Zorunluluğun ortaya çıkış1, Kant'a göre kanunların apriori olmasında görünmektedir. Apriori olmak zorunluluğu da içerir. Bu zorunluluk deneyden, yani tümevarımlarla elde edilen sonuçlardan çıkarılamaz. "Bir deney önermesinden zorunluluk çıkarmayı istemek, bununla da bir yargıya genel geçerlik sağlamayı ummak çelişkidir" (Kant, 1994:34).

Kant'ın ileride bahsedeceğimiz şekliyle sistemleştirdiği ahlak felsefesinde, "niçin yapayım?" sorusuna zorunluluk bildiren bir cevabı yoktur. Ancak tavsiyeci cevaplar vardır. Ahlak yasasına uymak niyeti ile soru sorana yol göstermek, tavsiyede bulunmak dışında herhangi bir otorite görünmemektedir. "Yapmalısın, çünkü yapabilirsin! Kant'ın burada (şeyleri etkileyen koşulsuz bir yapmalısın buyruğunun olanağı, temelini nerede bulduğu noktasındaki) vardığı sonuç budur. Bu sonuç teorik olan mantıksal bir sonuç değil, bir postulattır" (Heimsoeth, 1986:142). ${ }^{7}$

\footnotetext{
3 “Gerçek" tecrübeye, "hakikat" akla dayanır. Bu nedenle tecrübe edilen değişken, hakikat değişmezdir

4 "Ahlak yasası deneyden gelmez" (Kant, 1995:4)

5 "Ne var ki, doğa yasalarına göre belirlenme bittiği yerde, her tür açıklama da biter" (Kant, 1995:78)

6 İnsanın değer koyucu olması ile, değerlerin evrensel olması bir çelişkidir. Çünkü insan sırf akıl varlığı olmadığı gibi eğilimlerinden ve duygularından bağımsız olamaz. Nitekim Kant'ın da kanunları aklın apriori kavramlarında araması insanın duygularına güvenemediği içindir. Öyle iken, insanın nasıl olup da, değer koyabileceği, duygusallığından nasıl sıyrılacağı noktası kapalı kalmıştır.

7 Şüphesiz Kant da farkındadır ki, aklın insana emretmesi, tabii kanunların nesnelere hükmetmesi gibi değildir. Sadece aklın doğru bulması ile gereklilik göstermesinden ibaret bir emretmektir ki, bütün felsefi sistemlerdeki en büyük eksiklik de, bu emrin otoritesinin veya diğer yasa koyucu otoritelerin zayıflı̆̆ı, insana hükmetme olanaklarının hemen hemen
} 
“Ahlakilik”, Kant'a göre, içü̈dülerde, eğilimlerde ve eylemlerimizin sonuçlarında değildir. Onun için Kant fenomenler dünyasından gelen bütün etkilerin çok gerisinde bulunan ahlaki özümüze, salt istence kadar inmeyi dener. Kant, epistemolojisi ile tutarlılık arz etmesi için ahlak felsefesini sistemleştirirken insan tahlilini, felsefesinin her noktasında öne sürmektedir. "Kant, görünüş-gerçeklik, ya da fenomen-numen ayırımını insan varlığına uygulayarak ahlak olanağını kurtarır" (Cevizci, 1996:297). İnsanı ikiye ayırmakla ${ }^{8}$ Kant, doğadan ve doğanın mekanizminden bağımsız, ahlak yasasına uyma imkanı bulunan bir varlık konumuna getirmiş, böylece iradeye, ya da Kant'ın tabiriyle pratik akla etkili olabileceği bir alan bırakmışırı. İnsandaki "zeka gibi iradenin de kendine özgü karakteri, ilk formları özel kanunları vardır ve filozofumuz buna pratik akıl adını vermektedir" (Weber, 1993:323). İrade (tipk1 Descartes gibi) Kant felsefesinde insanın kabiliyetlerinin en üstünde bulunmaktadır. Sonuçlarına bakılmaksızın, sadece niyet noktasından davranışların değerlendirilmesi, iradenin Kant felsefesindeki yerini göstermektedir.

\section{2-Ahlaki Bir Varlık Olarak İnsan}

Kant'ın ahlak felsefesinin üç ana kavramı vardır. Bunlar; "iyi istenç", "buyruk" ve "özgürlük”tür. Özgürlük kavramı ileride tekrar ele alınacaktır. Diğer iki kavramın incelenmesine geçmeden önce, yine insanın tahliline kısaca bir göz atmakta fayda vardır.

Kant' a göre insan, aklı ve istemesi olan bir varlıktır. Akı1,

"İstemeyi etkilemesi gereken bir yeti olarak bize verilmiş olduğundan, doğa yeteneklerini dă̆ıtırken her yerde amaca uygun davrandiğına göreg aklın hakiki belirlenimi, başka herhangi bir amaç için araç olarak iyi olan değil, aklın mutlaka gerekli olduğu kendi başına iyi bir istemeyi ortaya çıkarmak olmalı” (Kant, 1995:11).

Başka amaçlardan Kant'ın kastı, insanın varlığını koruması, refahı yani mutluluğu gibi amaçlardır.

"Doğa bu amacın gerçekleştiricisi olarak bu yaratığın aklını görmekle pek isabetsiz bir gerçekleştirici bulmuşs olurdu. Çünkü bu yaratığın bu amaçla yapacağı bütün eylemler ve davranışın bütün kuralları, ona içgüdü tarafindan çok daha tam biçimde gösterilmiş olurdu; o amaca da akılla olabileceğinden çok daha emin bir biçimde ulaşılabilirdi" (Kant, 1995:10).

Kant, insanın yalnızca mutluluk için yaratılmadığını temellendirmek niyetiyle aklın mahiyetini göstermektedir. Çünkü hayvanlarda bulunmayan akıl, onların rahatla yaşayabilmelerine engel değildir. Öyleyse insanın fazladan bulunan aklı, ihtiyaçların tatmin edilmesi demek olan mutluluktan farklı bir amaca hizmet etmelidir. Çünkü akıl mutluluk hizmetinde kılı kırk yarmasından ötürü hiç de iyi bir kılavuz değildir. Bundan dolayı İnsan mutluluktan başka bir şey için yaratılmıştır. Yani, akıl ona başka bir dünyadan gelen bir sesi işittirir; ahlak yasası, ahlaki buyruk. "Psikolojik açıdan bakılınca ahlaki buyruğu, kendimiz için olduğu kadar başkaları için de geçerli bir ödev duygusuna bağlı istençsel bir eylem diye niteleyebiliriz" (Reichenbach, 1993:190). İnsanın tabiatın mekanizminin dışında bir şeyler yapabiliyor olması, onun ahlak yasasına uyabilmesini mümkün kılar. "İnsan doğal nedenler zinciri dışında bir takım şeyler yapabiliyor,

bulunmayışıdır. Bu yüzden Kant'ın, birazdan görüleceği gibi, “iyi niyet etik'i”, “olsa iyi olur” tavsiyesinden ileri geçmez.

${ }^{8}$ Kant'a göre insan hem nedensellik dünyasına hem de özgürlük dünyasına mensuptur. Özgürlük de iki türlüdür; doğanın nedenselliğinden ayrı eyleyebilmesi (negatif özgürlük), bu eylemenin ahlak yasasına göre belirlenebilmesi (pozitif özgürlük).

${ }^{9}$ Doğa nedensellik dünyası olarak tanımlanırsa ve "amaca uygun davranma" gibi bir özellik atfedilirse bu durumda Hıristiyanlığın pasif tanrısı yerine konulmuş olur.

Turkish Studies, 15(3) 
yapabilmeli de, onun karşısına ahlaksal istemlerle çıkılıyor. O bir gereklilik karşısında bırakılıyor" (Gökberk, 1979:82).

\section{- Iyi İstenç veya İyiyi İsteme}

Biraz önce bahsedildiği gibi Kant'ın etiği "bir (intention) niyet etiğidir" (Heimsoeth, 1986:126). Eylemlerin sonuçları yerine, eylemleri yapmaya iten öznel, ilkeye, yani maksimlere önem verir. Öncelikle Kant'a göre 'iyi' yalnızca "iyiyi istemek”tir. Dünyada, dünyanın dışında bile iyi bir istemeden başka kayıtsız şartsız iyi sayılabilecek hiç bir şey düşünülemeyeceğini (Kant, 1995:8) savunan Kant'ın bu görüşü öne sürmesinin arkasında yatan düşünce, insanın sahip olduğu her duyguyu ve kabiliyeti, hem iyiye hem de kötüye kullanılabilir olmasıdır. Cesaret gibi güzel kabul edilen bir duygu bile, kötüye kullanılabileceğine göre, bizzat davranışın sonucuna bakarak iyi veya kötü gibi genel bir ölçüt çıkarılamaz. Öyleyse insanın bu davranışının arkasındaki niyeti esas alınmalı, sonuç hesaba katılmamalıdır. "Kant'ın sonuçlar yerine ilkelerle ilgilenmesinin, ahlakın temeline ödevi ve ödev duygusunu yerleştirmesinin en önemli nedeni, onun tüm insanların ahlaklı olabileceği konusundaki sarsılmaz inancıdır" (Cevizci, 1996:100). Niyetin esas alınması Kant'ın evrensel bir ahlak kanunu arayışının zaruri bir sonucudur. Çünkü sonuçların istenildiği gibi olması tamamen insanın elinde olmadığından "ahlakilik" sonuçlara bakılıp kararlaştırılamaz. Ahlakilik, insanın aklının var olmasıyla yaratılışının ona ilham ettiği “ödev” kavramına uymakla ortaya çıkar. İnsanın mutluluk için yaratılmadığını temellendirmeye çalışan Kant, geriye kalan aklın sesi demek olan "ödev" kavramın ${ }^{10}$ ahlak felsefesinin temeline yerleştirir. "İyiyi isteme" den başka iyi şeyin var olmadığını vurgulayan Kant' a göre bu "iyiyi isteme" ancak "ödev niyetiyle isteme" anlamındadır. ${ }^{11}$

Kant'ın ahlak felsefesini temellendirdiği insan kavramının iki yönü olan akıl ve doğal yönünden; doğal yönü, içgüdüler ve eğilimlere sahiptir. Aklın sesi olan ödev ile bu doğal eğilimler karşılaşınca ya çatışır, ya uyuşur. Uyuşma varsa bu -iyi- değildir, rastlantıdır. "İyi" hiç koşulsuz ödevden çıkmış olmalı. Eğer davranışın istenmesinde, hiç bir eğilimin etkisi olmadan, yalnız ödev kastıyla yapmak düşüncesi etkili olmuşsa, o zaman o davranışta ahlaksal bir değer vardır. Eylemi yapan, "hiçbir eğilim duymadan yalnız ve yalnız ödevden dolayı" (Kant, 1995:13) eylemini yapmış olmalıdır. Eğilimlerin eylemde payı olmamalıdır.

"Tam ödev derken, eğilimler uğruna hiçbir istisna kabul etmeyen ödevi anllyorum” (Kant 1995:38).

Kant'ın eğilimler ile akıl arasında kalan ‘insan'ı aslında iyi veya kötü değildir.

\footnotetext{
${ }^{10}$ Eylemlerimizin ahlak yasasına uygun olup olmadığını, insanı amaç kabul etmek şartıyla eylemin evrenselleştirilmesi durumunda kendisini ortadan kaldıran bir hükme dönüşmemesiyle anlayabiliriz. O yüzden ödev; aynı zamanda genel geçer bir yasa olmasını isteyebileceğimiz maksime göre eylemde bulunmaktır (Kant, 1995: 38).

${ }_{11}$ Ancak bu iyiyi isteme'ye dayanan, sonuçları hesaba katmayan bir ahlak anlayışının bir çok çelişkileri vardır. Sırf ödev kastı olmaksızın birisine yardım etmiş olmak, Kant'ın ahlak felsefesinde kesinlikle iyinin içine dahil değildir."Diğer insanlara yardım etmeye yönelik doğal eğilimin ne açık çarpıtılması bu!" (Reichenbach, 1993:48). İki ödev duygusu birbiriyle çatıştığında, Kant'ın ödev ahlakının vereceği bir cevap yoktur. Ülkemi savunmak ve ailemle kalmak gibi iki ödev duygusu çatıştığında ne yapmam gerektiğinin cevabı yoktur. Niyeti şüphesiz hiç hesaba katmamak yanlıştır. Ancak "bir eylemin ahlaksallığını onun sonuçlarına bağlamak gibi, sonuçların hesaba katmadan salt yapılışındaki niyete bağlamak da aynı ölçüde sağduyuya aykırı görünmektedir” (Arslan, 1994:112). Yalnızca niyet ahlakiliğin ölçütü olamaz. Çıkar çatışması gibi durumlarda ödev ahlakının çelişkileri ve güçlükleri ortaya çıkmaktadır. "Güçlükler, çoğunluğun yeğ tutularak, kişisel çıkarın başkalarının çıkarına feda edilebileceği bir ilkeyi zorunlu kılan siyasal felsefede özellikle su üstüne çıkar" (Russell, 1994:58).
} 
"Gerçekte tecrübe gösterir ki, insan iki aşırılık arasında (yani tam olarak kötü ve tam olarak iyi arasinda) orta bir yerdedir" (Kant, 1960:18).

Bu ne iyi ne de kötü olmama Kant'a göre insanın tabii haliyledir. Yani, insanda yalnızca iyiye ve yalnızca kötüye sevk eden zorlayıcı bir tabiat yoktur. İyilik ve kötülük niyete bağlı olarak eylemde bulunma neticesinde ortaya çıkar. "İyi ya da kötü eylemlerle ilgilidir. Kişinin duyum durumuyla değil. Bir nesne iyi ya da kötü sayllacaksa bu ancak eylem türünden istencin maksiminden dolayıdır. Bu yüzden iyi ya da kötü diye nitelenebilecek insan (istenciyle değer koyan, hüküm veren olduğu için) eylemde bulunan kişinin kendisidir. Bir nesne değildir" (Kant, 1994:103). İnsan istencini kötüye kullanmakla kötü olur. Yoksa, kötü olduğundan veya yaratıldığından dolayı kötü değildir. İyiyi de tercih edebilirdi. Kötüyü tercih edebilenin iyiyi de tercih edebilmesi mümkündür. Kant'ın kötü olarak sınıflandırılamayacağı iddiasında olduğu "nesne", insanın duyumlamasıyla hüküm veremeyeceğini, verdiği hükmün iyi veya kötünün ölçütü olamayacağını kabul ettiğinden dolayı bizzat kötü değildir. Duyum iyi ve kötü yargısının kaynağı olamaz.

"Yargıda bulunma duyudan başka, (ayrica) usu gerekser" (Kant, 1994:104).

Kantın ödev niyetiyle, ödeve uymak kastıyla iradeyi yönlendirmek dışında bir iyi olmadığını kabul ettiğini belirtmiştik. Ödev dışında hiç bir şeyin istencin belirleme nedeni olmamasını, olursa eylemin ahlakiliğini kaybettiğini savunur. Mutluluk herkesin elde etmeyi istediği şeydir. Fakat Kant'a göre, "kişinin kendi mutluluğu istencin belirleme nedeni yapılırsa, bu, ahlaklılık ilkesinin karşıtı olur" (Kant, 1994:68). Çünkü iyiyi istemenin ödevden başka hiçbir şartı ve temeli olmamalı, evrensel olması için de, ferdin mutluluk kastı bulunmamalıdır. ${ }^{2}$ Mutluluk gayesi objektif zorunluluğu ortadan kaldırır. O zaman Kant'a göre, iyi ve kötüyü tespitte ortak nokta yakalanamaz.

Dolayısıyla iyi istenç kavramının iki belirtisi vardır;

-Eylem salt ödevden doğmuş olmalı

-Ödevden doğan ahlaki eylemin değeri, varllmak istenen sonuçta değil, kararı verdiren öznel ilkede yani maksimde aranmalıdır.

Eylemin dışarıda bulunan bir sonuç yüzünden değil, ancak kendisine dayandığı maksim yüzünden iyi olduğunu söylemiştik. Bu ilke apriori veya posteriori olabilir. Kişi istencini ya apriori bir kurala ya da doğal motiflere (duygu vb.) göre belirleyebilir. Ama bir eylemin iyi olabilmesi için apriori bir motife göre yani aklına buyruğuna, ödeve göre belirlenmiş olmalı. Dolayısıyla sözü geçen maksim ödev maksimidir. Ödev de aklın buyruğu olduğundan zorunlu ve tümel geçerdir.

Kant yasa aramaktadır. Ödev de yasaya duyulan saygıdan doğar. "Saygı”, Kant'a göre yasaya uymaktaki itici güçtür. Sayg1, "istemenin yasa tarafından belirlenmesinin ve bunun bilincinin adıdır" (Kant, 1995:17). ${ }^{13}$

\footnotetext{
${ }^{12}$ Kant'ın bu görüşü Hobbes'un “insan insanın kurdudur” sözüyle içerik olarak paralellik taşır. Çünkü çatışma nedeni insandaki dizginlenemeyen bireysel haz duygusudur, hazzın amacı da mutluluktur. Kant, mutluluğun amaç olması durumunda evrenselliğin yakalanamayacağını, bireysel yargıların süreceğini vurgular.

${ }^{13}$ Kant'ın tespit ettiğini düşündüğü bu "yasanın özneye etkisi” demek olan saygının yasa'nın kurallarını tatbik ettirmekte bir etkisinin olabileceği şüphelidir. Saygıyı itici güç olarak kabul etmek, insanı sırf akıl varlığı olarak tasavvur etmenin sonucudur. Halbuki ahlakiliğin eylemlerdeki ölçütü olarak Kant'ın öne sürdüğü ödev kavramı, insanı önce ikiye ayırmak, onda bir de akla uygun hareket etmeyen bir doğal yönün varlığını kabul etmek düşüncesinden çıkmıştır. Bu yüzden duygu ve doğal eğilimlerden sıyrılamayan insanın, saygı gibi bir duyguyla ahlak yasasına itaat ettirebileceğini düşünmek bir çelişkidir.
}

Turkish Studies, 15(3) 
Kant yasaları da insan gibi doğa ve ahlak yasaları olmak üzere ikiye ayırır:

a- Doğa yasaları, zorunlu ve tartışılmazdır. Fenomen dünyasında mekanizm hakimdir. Burada özgürlük yoktur. Halbuki ahlak yasalarının mümkün olabilmesi için özgürlüğün bulunması gerekmektedir. "Kant görünüş-gerçeklik ya da fenomen-numen ayırımını insan varllı̆ı̆ıa uygulayarak ahlakın olanağını kurtarır" (Cevizci, 1996:297).

b- Ahlak yasaları; gereklilik yasalarıdır. İstenci özgür olan süjeye seslenir. Zorunluluk ve mekanizm yok. Ahlak yasasının kaynağı akıldır. Aklın emretmesi ise gereklilik şeklinde ortaya çıkar. "İnsanın ahlaki eylemlerindeki akıl ilkesi, bir buyruk, gereklilik gösteren bir ilke niteliğini taşır. Bu ilkeler, insanın iradesini, eylemlerini, doğada nedensel yasaların doğa olaylarını yönettiği gibi yönetmezler. Onlar sadece "yapmalısın" buyruğu ile bir gereklilikle ortaya çıkarlar" (Heimsoeth, 1986:126). Ahlak yasası insanın akıl tarafina hitap ederler. İnsan'ın mahiyeti ahlak yasasına uyabilecek yaratılıştadır.

Ahlak yasasına uymak, ahlaki olmak için Kant'a göre kafi değildir. "Ahlakça iyi olması gereken için, ahlak yasasına uygun olması yetmez, aynı zamanda ahlak yasasının uğruna yapılmış olmalıdır. Yoksa o uygunluk yalnızca rastlantısal ve belirsizdir" (Kant, 1995:5). Yine Kant' a göre "yasaya uygun eylem kendiliğinden iyidir" (Kant, 1994:105). Yani iyi ve kötünün tespitinde ahlak yasası dışında müracaat edilecek bir merci yoktur. Başka bir merci tanımak, insanın özgürlüğünü kısıtladığı gibi, mesela Tanrı'nın, fiillerin iyi veya kötülüğünün tespitine karıştırılması, adam öldürmenin biz çirkinliğini bilebildiğimiz halde, bunun Tanrı'nın yasağından dolayı çirkin olması manasına gelir, eğer Tanrı yasaklamasa iyi olabilirdi gibi yanlışlığın ortaya çıkacağı apaçıktır. ${ }^{14}$ Dolayısıyla Kant' a göre ahlaki fiili biz, Tanrı emrettiği için değil, iyi olduğunu bildiğimiz için ${ }^{15}$ yaparız ve iyiye Tanrı emri gibi bakarı. ${ }^{16}$ Kant'a göre ahlakiliğe hiç bir şey müdahale etmemelidir. "Eyleme ahlaksal değer verebilen şey, ne korku (Tanrı korkusu) ne de eğilimdir. Yalnızca yasaya saygı güdüsüdür" (Kant, 1995:58).

\section{3- Buyruk}

Kant buyruk ve emri birbirinden ayırır; "isteme için zorlayıcı olduğu ölçüde nesnel bir ilkenin tasarımına emir (aklın emri), bu emrin formülüne de buyruk denir” (Kant, 1995:29). Kant bu cümlesiyle insan iradesinin, aklın emirlerine uymak zorunluluğunun olmadığını ya da zorunlu itaatin bulunmadığını ifade eder. Buyruklar Kant' a göre ikiye ayrılır;

I- Şartlı (Hypothetical) Buyruk; bu tarz buyruklar "kanun değil ilkedir" (Aydın, 1991:34). Şartlı buyruk insandan bir şeyi yapmasını istemesi anlamında doğrudan akla dayanmaz. Şartlı buyruklar "eğer" kelimesini ihtiva ederler. Bundaki zorunluluk dişarıdan geliyor. Dolayısıyla "eğer" ile ifade edilmiş olan arzu edilen şeyden vazgeçildiğinde buyruktan da vazgeçilmiş olur. Kayıtlı olarak buyurma olduğundan, Kant'a göre şartlı buyruklar ahlaki olamazlar. Bu buyrukların

\footnotetext{
${ }^{14}$ Öldürmek mutlaka çirkindir yargısını bizim bilebileceğimiz iddiası, meşru müdafaanın hükmünü muğlak bırakmıştır. Haksız yere öldüreni öldürmek hangi akli kritere göre çirkindir sorunu ortaya çıkar.

${ }^{15} \mathrm{Bu}$ görüş İslam dünyasındaki iyi ve kötünün, güzellik ve çirkinliğin kendi başına bağımsız olarak var olduğunu iddia eden Mutezile mezhebinin görüşleri ile paralellik arz eder.

${ }^{16}$ Kant felsefesindeki açmazlardan biri budur. İleride göreceğimiz gibi, Tanrı'nın varlığını kabul etmek niçin vahyin imkanını düşündürtmesin? Tanrı'nın insana (erdem ve mutluluk bağını kurmak gibi) ve evrene müdahalesi varsa, doğru ve yanlışın tespitinde niçin ölçü alınmasın? Eğer Tanrı'nın müdahalesi yoksa, öyleyse onu bir postulat olarak kabul etmenin anlamı nedir? -Kant'ın Tanrı anlayışında göreceğimiz gibi- Kant'ın Tanrısının mahiyeti meçhuldür. Ne Teistlerin Tanrısına ne de Deistlerin Tanrısına benzer, Kant'ın kendisi teist bir anlayışa sahip (Aydın, 1991:136) olmuş olsa bile.
} 
zorunluluğu ön koşula dayanır ve buyruk düşünüldüğünde, onun iyi içereceği de önceden bilinmez. "Hypothetical buyruklar maddi amacı olan buyruklardır" (Heimsoeth, 1986:130).

II- Kesin Buyruk (Categorical Imperative); Kant'a göre as1l ahlaki olan buyruk bu buyruktur. Şartlı buyruk olarak şu cümleyi söyleyebiliriz; “-Eğer doğruyu söylemezsen, güç durumda kalırsın". Bu cümleyi kesin buyruğa çevirirsek ifade böyle olur; "Her ne olursa olsun doğruyu söyle!" Kant için ahlaki olan ikincisidir. Kategorik imperatif tümel olarak geçen, zorunlu olan koşulsuz gerekleyen emirdir. "Zorunluluğu hiç bir ön koşula dayanmaz" (Kant, 1995:36). Bu buyruk düşünüldüğünde muhtevası bilinir. "Kesin bir buyruk düşündüğünde ise, neyi içerdiğini hemen biliyorum" (Kant, 1995:37). Koşulsuz buyurduğu için içgüdü ve eğilimlere ilişkin deney dünyasındaki sonuçları emretmez. Çünkü deney dünyasından elde edilenler apriori değil, ampiriktirler. Deney dünyasından gelen veriler evrensel olamazlar. Kategorik imperatif kendi kendisini emreder. Kategorik gereklilik "deneyimin tek tek olaylarından birisi değil, aklın kendisinin bir olayıdır. Salt pratik aklın temel fenomenidir" (Heimsoeth, 1986:128).

Kategorik buyruk yani "insandan insan olduğu için belli şeyler yapmasını isteyen ahlak yasası" (Cevizci, 1996:297) evrendeki fizik kanunları gibidir. "Ancak bütün fiziki varlıklar şuursuz veya zorunlu olarak fizik kanununa uyarken sadece ak1l sahibi varl1klar, kanun fikrine uygun olarak hareket edip etmeme kabiliyetine sahiptirler" (Kılıç 1992:36). Kant'ın ifadesinde doğa ve ahlak yasasının yeri belirlenir; "üstümde yıldızlı gökler (yani nedensellik dünyası), içimde (özgürlüğün formülü olan) ahlak yasas1" (Kant, 1994:241).

Kesin buyruğun ifadesi şudur; "Aynı zamanda genel bir yasa olmasını isteyebileceğin maksime göre eylem de bulun" (Kant, 1995:38). Yani maksiminin eylemi evrensel genel kural olduğunu farz ettiğinde, eğer çelişki doğmuyorsa, o eylemi yapabilirsin demektir.

"Zor durumda olduğunu düşünen herkes, tutmama niyetiyle kafasına eseni yapmaya söz verebilir, gibi bir yasanın genelliği, söz vermeyi ve bununla amaçlananı olanaksı bile kılardl; çünkü kimse kimsenin söz verdiğine inanmaz, boş laf saydı̆̆ bütün bu söylenenlere de gülerdi" (Kant, 1995:39).

Böylece maksimin eylemi genel yasa olduğunda bir çelişki doğmazsa, akla dayalı bir yasanın eylemi olarak kabul edilebilir demektir. Kant kesin buyruğun muhtevasını genişletir.

"Insan ve genel olarak her akul sahibi varlık, şu veya bu isteme için rastgele kullanılacak sirf bir araç olarak değil, kendisi amaç olarak vardır; ve gerek kendine, gerekse başka akıl sahibi varlıklara yönelen bütün eylemlerinde hep aynı zamanda amaç olarak görülmelidir" (Kant, 1995:45).

Kant böylece genel-geçer bir yasa olması farz edildiğinde kendisiyle çelişmeyecek olması durumunda ahlaki saydığı maksimin bir postulatı olarak insanı amaç konumuna yerleştirir. ${ }^{17}$

Kant zorunlulukla beraber, ödev kavramını da ahlak felsefesine yerleştirdiği için, ahlak kanununun dışarıdan değil, insanın kendisinden kaynaklanması gerektiğini, aksi halde eylemin ahlaki olamayacağını, yasayı insanın dışında arayanların bu emeğinin boşa gittiğini belirtir. Ödevi de ihtiva eden, kesin buyruğun bu diğer ilkesine Kant "istemenin özerkliği ilkesi" (Kant, 1995:50) der. Kant bu ifadesiyle kendisinden öncekilerden farklı olarak iyi ve kötü kavramının ahlak yasası içindeki yerini değiştirir;

\footnotetext{
17 Ancak Kant, evrensel bir maksim olabilme düşüncesindeki dakikliğine rağmen, evlenmemek gibi insanı amaç edinmeyen bir eylemle evrenselliğe zıt ve çelişik düşer.
} 
"Ahlak yasasının temeline konulması gereken (gerektiği kabul edilen) iyi ve kötü kavraminın ahlak yasasından önce değil, tersine bu yasadan sonra ve onun aracıllğıyla belirlemesi gerekmektedir" (Kant, 1994:106).

İnsan akıl sahibidir. Bu vasfıyla kendisi dışındaki doğadan ayrılır; "akıl sahibi doğa kendi kendine amaç koymakla geri kalan doğadan kendini ayırır” (Kant, 1995:55). Kant'ın insanı yasa koyucu, (a priori, yasa koyucu) olarak kabul etmesinin sebebi, insanın en kolay olarak kendi koyacağı yasaya uymasını mümkün görmesi, apriori kavramları ortak görmekle de evrenselliği yakalayabileceğini düşünmesidir.

Kant, "eyleminin maksimi evrensel kanun olacakmış gibi hareket et" demekle herkesin ortak bir noktayı yakalayabileceğini düşünür. Akı1 sahibi varlıkların evrensellik gözeterek ortaya koyacakları maksimler, insanları "amaçlar krallığı" kavramına götürür,

"Kendini ve eylemlerini yargllayabilmek için her akul sahibi varlı̆̆ın istemesinin bütün maksimleri aracılı̆̆ ile kendini genel yasa koyucu olarak görmesini gerektiren bir akıl sahibi varlık kavramı ona bağll olan çok verimli bir kavrama, bir amaçlar krallı̆̆ kavramına götürür. Krallık derken ise, çeşitli akıl sahibi varlıkların, ortak yasalar aracıllğglyla kurulan sistematik birliğini anlıyorum" (Kant, 1995:50).

Elbette bu ancak bir idealdir. Daha önce söylediğimiz gibi, Kant'ın ahlak felsefesinin ilkelerinin uygulanabilmesi için insanın sırf akıl varlığı olması gerekir. Halbuki insan duygu ve eğilimlerinden hiçbir zaman tam anlamıyla sıyrılamaz. Dolayısıyla sırf akıl varlığı olarak tasavvur edilen insanlar için mümkün olan ilkeler geçerliliklerini yitirirler. Halbuki, "Kant, amaçlar ülkesi ile, objektif amaçların düzenli bütününü, hiçbir koşulu bağlı olmayan değerlerin taşıyıcısı olan varlıkları, akıl sahibi olma, insan olma onurunu kastediyor" (Heimsoeth, 1986:136). Dolayısıyla idealist bir tasavvurdan başka herhangi bir anlamı yoktur.

\section{4-Pratik Akıl}

Eylemlere ilişkin doğruluk kriterlerini arayan, hakikati tespit eden ve bir anlamda pasif olan teorik akla karşılık "pratik akıl teorik akıldan farklı olarak davranışlara yönelik ödev adında kurallar getirir" (Elmas, 2015:109). Pratik aklın hedefinde "en iyi”nin gerçekleşmesi vardır. Bu düşünce yöneliminde Kant pratik aklın postulatı olarak üç postulatı yerleştiriyor:

a- Özgürlük Kavramı: Kant'ın, insanı numen olarak hür, fenomen olarak bağımlı kabul etmesinden dolayı, buyrukları dinleyebilecek insanda bir alan kalmıştır ki, bu numen alanında bulunan özgürlük kavramıdır, özgürlük olmazsa, emretmenin anlamı kalmaz. Özgürlüğü bütün akıl sahibi varlıkların istemesinin özelliği olarak varsayılmalıdır (Kant, 1995:66) diyen Kant, bu cümlesiyle insanın özgürlügünün ispatlanamayacağını, var gibi hareket edilmesi gerektiğini, daha doğrusu varllğ 1 ispatlanamayacak bir alan olduğunu ifade ediyor. Kant'a göre istenç özerkliği, bütün ahlak yasalarının ve onlara uygun ödevlerin tek ilkesi olduğu için (Kant, 1994:66), bu ilkenin var olması zorunluluğundan hareketle Kant, var olduğunu iddia etmiş oluyor. "Kant, özgür olduğumuzdan ötürü sorumlu olmadığımızı, tersine sorumlu olduğumuzdan ötürü özgür olmamız gerektiğini ileri sürer" (Arslan, 1994:111). Koşulsuz buyruğa uyulabilmesi için insanın koşulsuz özgür olması gerekmektedir. "Koşulsuz buyruğun geçerliği gerçekleşmesi için özgürlügü var saymak kaçınılmazdır, çünkü istenç içgüdülere bağımlı olmaktan kendini kurtaramazsa, insanın karşısına bir buyrukla çıkmanın hiçbir anlamı kalmaz" (Gökberk, 1979:83).

Kant insanın hem otonomluğunu, yani "itaat edeceği kanunu bizzat 'isteme'nin kendisinin koyması" (Kılıç, 1993:70) düşüncesini, hem de 'isteme'nin koyduğu kanuna itaat edebilmesi için özgür olması gerektiği düşüncesini ahlakiliğinin temeline koyar. "Ancak insanın bu özgürlüğü bir 
yasasızlık demek değildir. Tersine, bir yasaya bağlı olmaktır. Yalnız bu yasa doğa yasası değil de, insanın kendi yasası olan ahlak yasasıdır. Koşulsuz buyruktur, özerkliktir”' (Gökberk, 1979:83). Ancak Kant'ın birinci postulatı olan özgürlük kavramının mahiyeti meçhul, Tanrı kavramıyla ilgisi belirsizdir. ${ }^{18}$

Kant'ın ikinci ve üçüncü postulatları olan ruhun ölümsüzlüğü ve Tanrı kavramına geçmeden önce, bu iki postulatın konmasına sebep olan "en yüksek iyi" ya da "summum bonum" kavramını bilmek bu iki kavramın anlaşılabilmesi için zaruridir.

En yüksek iyi kavramı, istemenin ve hislerin ahlak kanununa tam uygunluğu demek olan erdem ile, her şeyin arzular istikametinde olup bitmesi demek olan mutluluğu içeren bir kavramdır. Ahlak kanununa tam uygunluk olan erdemi, mutluluğun takip etmesi gerekirken tesadüfler hariç, bu ikisi pek bir araya gelmemektedir. Fakat "pratik ak1l, erdem ile mutluluk arasında zorunlu bir bağ ister" (Kılıç, 1992:47). Ancak böyle bir zorunluluk olmadığı gibi, en yüksek iyiye ulaşmak da süreli bir zamanda mümkün değildir. İşte Kant, süresiz ve sonsuz bir zamanda en yüksek iyiye ulaşmak idealinin mümkün olması için ruhun ölümsüzlüğünü, erdem ile mutluluk arasındaki bağı da zorunlu kılabilmek için, bunu gerçekleştirmeye muktedir olan Tanrı'nın varlığını postulat olarak koyar. Kant, "Tanrı'y1 ahlak kanununun genel geçerliği için değil, en yüksek iyinin gerçekleşebilmesi için bir postulat olarak koyuyor" (Aydın, 1991:43). Kant'ın felsefesinde Tanrı'nın yeri ve önemi, insanın erdem ve mutluluğunu gerçekleştirme noktasındadır. Bizzat Tanrı, felsefesinin konusu değildir. Bu anlamda deizme daha yakındır.

En yüksek iyinin sonucu saadet ve mutluluktur. Ahlak yasası bizi bu mutluluğu gerçekleştirmeye sevk eder. "İçinde yaşadığımız fenomenler dünyasıyla yetinmemiz, izin vermeyen ve gözlerimizi tabii varlığımızın ötesine çeviren ahlak duygusu bizi bir başka durumla daha karşı karşıya getirir. Ahlak kanunu bizi en yüksek iyiyi gerçekleştirmek için çaba harcamaya zorlar" (Aydın, 1991:29). Görevimiz gücümüz yettiği nispette en yüksek iyiye yaklaşmak, onun elde edilmesi için çaba harcamaktır. Bütün konulan postulatların, ilkelerin, maksimlerin ve "ahlak kanununun özü, seni saadete ehil kılabilecek ne ise onu işle, demektir" (Janet, 1978:328). Kant her ne kadar kesin buyruk'un dile getirdiği "ödev"” dışında bir gayenin istençte etkili olmamasını söylüyorsa da mutluluk menfaati göz ardı edilememiştir.

b- Ruhun Ölümsüzlü̆ğ̈̈ Kavramı: En yüksek iyiye "ancak sonsuza dek uzayan bir oluş içinde varılabileceğinden” (Heimsoeth, 1986:151) ruhun ölümsüzlüğünün postulat olarak konulması gerektiğini, Kant'ın "teorik olarak kanttlanamayacak" (Heimsoeth, 1986:148) olan bu ikinci postulatı, ihtiyaç ve arzudan dolayı koyduğunu göstermeye çalışmıştık. Kant'ın ruh ve Tanrı postulatlarının kaynağı ümittir. Çünkü insan için ümit olmazsa, ahlak kanununa uymak gibi bir düşüncesi olamaz. İnsan için en çok ümit edilen şey, ebediyettir, yok olmamadır. Nitekim en büyük ceza da, bunun aksi olan idamdır. Ebediyeti gerçekleştirecek ve mutluluğa layık olmak demek olan fazilet ile mutluluk arasında zorunlu bağı kurabilecek bir varlığın postulat olarak konması gerekiyor. Bu varlık, en yüksek iyinin gerçekleşebilmesinin zaruri şartı olarak konan Tanrı'dır.

c- Tanrı'nın Varlı̆̆l: Tanrı'nın, Kant felsefesinde bizzat değil, ancak insan ideallerinin gerçekleşmesi noktasında bir rolü olduğunu söylemiştik. "Tanrı'ya inanma böyle bir ümidin (en yüksek iyinin, insan ideallerinin elde edilebilmesinin) vazgeçilmez temeli oluyor" (Aydın,

\footnotetext{
${ }^{18}$ Kant insanı, fenomen ve numen ayrımına paralel olarak hem nedenselliğin hem de özgürlük dünyasının üyesi olarak tanımlar. Bir şey hem var hem yok olamayacağına göre, hem olduğu hem de olmadığı şey olamayacağına göre, Kant'ın insan tanımının zorunlu sonucu insanın hem Platon'da hem Descartes'de olduğu gibi mekanizmin dışında olan bir yönünün yani ruhunun sadece postulat olarak değil, gerçekte de var olması şartıdır.
} 
1987:78). Ümit vermeyi olanaklı kılma dışında Kant'a göre Tanrı'ya ahlak felsefesinde ihtiyaç yoktur;

"Ahlak, mantı̆̆ kendisini kayıtsız şartsız kanunlara bağlayan tamamen hür insan kavramına dayandirıldiğg takdirde, ne onun üzerinde ona vazifesini idrak ettirecek bir başka varlık fikrine, ne de ona görevini yaptıracak kanunun kendisinden başka bir dürtüye ihtiyacl vardir" (Kant, 1960:3).

Kant'a göre Tanrı kabul edilmeden de ahlaklı olunabilir, ancak en yüksek iyinin gerçekleşme ümidi kaybolur.

İnsanı Tanrı'nın varlı̆̆ 1 fikrine götüren zihinsel yatkınlıktır, "Bir insanın dürüst olması veya olmaması, adaletli veya zalim olması bir ve aynı şey olamazdı. İnsan erdemin karşılıksız ve suçun cezasız kalacağını kabul edemezdi. İçinden gelen bir ses adeta bunun böyle olamayacağını ona duyurur gibiydi” (Aydın, 1991:28). Ancak Tanrı bilginin konusu değil inancın konusudur. Tanrı, Kant'a göre, inancın konusu olmazsa insanın özgürlüğünden ve ahlakın otonomluğundan söz etmek mümkün olmaz. Kant, bu yüzden birazdan bahsedeceğimiz ahlak delili dışındaki kozmolojik, ontolojik gibi delillerin geçersizliğini ispatlama gayretindedir. Ancak Kant’ta inanma ve bilme ilişkisi, sınırları açık değildir. Akla dayalı bir ahlak felsefesi ve en iyiye ulaşabilmek için postulat olarak konmuş Tanrı kavramı!

Kant'ın felsefesinde din, daha doğrusu, doğru din; ahlak kanunlarının ilahi buyruklar şeklinde anlaşılmasıdır. Kant için, Tanrı gibi, dinin de ahlak kanununa yardımcı olma noktasında bir yeri vardır. İbadetin anlamı da ahlak kurallarına uymaktır. Kant'a göre, ahlak kurallarıyla, yetkin olduğu için Tanrı'nın emirleri arasında zitlık bulunmaz. Kant’a göre "Tanrı ahlak kanununa ters düşen şeyleri asla buyurmaz" (Aydın, 1991:130). ${ }^{19}$

Tanrı ve din Kant'ın felsefesinde doğrudan konu değildir. Kant, ahlakının temeline aklı yerleştirdiği için doğru ve yanlışı, ahlak kanununun tespitini akla vermek düşüncesindedir. Yani ahlak akıldan başlamalıdır. Eğer Tanrı'dan başlarsa o zaman aklın, ahlak kanununu, doğru ve yanlışı bulması imkanından mahrum olunur. Bu yüzden Kant, ahlakiliği Tanrı'nın emirlerinden başlatmaz. İnsanın doğru ve yanlışı bulması, aklının iyi ve kötüyü tespit edebilmesi demek, iyi ve kötünün insandan bağımsız olması demektir. İnsandan bağımsız olmak demek ise, bazı eylemlerin doğruluğunu veya yanlışlığını anlamak için Tanrı'ya muhtaç olunmaz demektir. Yani M. Aydın'ın tabiriyle, "insan tarihte ortaya çıkmış belli bir vahy tecrübesinden müstakil olarak iyi ve kötü konusunda bir takım bilgilere (söz gelişi adam öldürmenin veya bir insana işkence yapmanın kötü olduğunu anlamak için herhangi bir buyruğa ihtiyaç duymayacak bilgilere) sahiptir" (Aydın, 1987:240). Ancak, bazı şeylerin iyi veya kötü olduğunun bilinebilir olması veya bilinebilir olduğunu kabul etmek, iyi ve kötünün, kendi başına bir yargıdan bağımsız olarak var olduğunu göstermez. Bizim bilgimiz, evrenin ve insanın yapısının bazı şeyleri doğru bazı şeyleri yanlış ilham etmesine dayanır. Aklın birinci vazifesi kural koyucu olmaktan çok saptama ve tespittir.

\section{Ahlak Kanıtı}

Kant'ın Tanrı'nın varlığını ispat etmek için ya da iddia etmek için öne sürdüğü delil ahlak delilidir. Tanrı'yı bilgi konusu olarak ele alan kozmolojik, ontolojik, teleolojik türden delilleri tenkit eder. Ancak teleolojik delile diğerlerinden biraz daha çok önem verir. Kant'ın ahlak kanıtı,

${ }^{19}$ Mutezile mezhebinin, vahyin önemini, aklın bulduğu doğrulara bir otorite, bir zorlayıcı olması noktasında gördüğü gibi, Kant da dinlerin önemini, ahlaka faydası olması noktasında, ümit vermeleri noktasında, "inançsızlığın insanı ahlaki bir çöküntüye götüreceğini açıkça ifade etmesi” (Aydın, 1991:47) nedeniyle inanmanın insana yardımcı olması noktasında görmektedir.

www.turkishstudies.net/turkishstudies 
"teizmin temellerini, insan varlıklarının ahlaki temellerinde bulma, Tanrı'nın varoluşunu insandaki değer duygusuyla açıklama tavrı için kullanılan bir terimdir" (Cevizci, 1996:22). Bu kanıt doğrudan (teslis, enkarnasyon vs. ile ilgili değil) Tanrı'nın varlığıyla ilgili bir kanıttır. Diğer delillerden en önemli farkı, diğerleri gibi iddialı olmayışıdır. "Kant diğer delillere tercih ettiği bu delilin dahi, ruhumuzun bir görüşü, adalet ihtiyacımıza karşı verilmiş bir emniyet sevinci, hasılı, ispat edici bir delilden ziyade inanıştan ilham almış bir delil olduğunu, bazı yerlerde anlatmıştı" (Janet, 1978:329). Kant Tanrı'nın varlığının objektif olarak ispat edilebileceğini kabul etmediği için Tanrı'nın varlığının bizzat ispatını değil, ahlaki davranabilmenin zaruri şartı olarak kabul edilmek zorunda olduğunu düşünür. Kanıt, Tanrı'dan şüphe eden için bir ispat değil, ahlaki düşünmek isteyen için Tanrı'nın varlığını kabul etmeyi zorunlu gösteren formüle edilmiş bir düşüncedir. Kant'ın ahlak delili kısaca şöyle özetlenebilir;

-Pratik akıl insana en üstün iyiye ulaşmak için çalışmayı emreder.

-En üstün iyi için çalışmak bir erdemdir ve mutluluğa layık olmaktır.

-Mutluluk dünyadaki her şeyin arzu ve isteklere uygun olmasıdır.

-Fakat insan erdemle mutluluk arasında zorunlu bir bağ kurabilecek güçte değildir.

-En üstün iyinin gerçekleşebilmesi için bu bağın kurulması zaruridir.

-Bu bă̆g kurabilecek yetkin bir varlık gereklidir.

-Bu yetkin varlık Tanrı'dır.

Görüldüğü gibi Kant'ın ahlak delili iddialı olamayacak bir delildir. Çünkü postulatlardan hareketle, yine bir postulata varmaktadır. Öyleyse kanıt olarak nitelendirilemez. "Ahlaklı olmak istiyorsam Tanri'yı inkar etmemeliyim" demek istiyor Kant.

Ancak bu delili biraz farklı bir şekilde ele alırsak, yani insanın ahlaki bir yapısının var olduğunu göz önüne alarak metodu değiştirirsek, o zaman şöyle bir sonuç çıar;

-İnsan, kendisine yapılan iyiliklere karşı minnet ve şükran hissi duyma özelliklerine sahip bir varliktır.

-Sevgi duygusu sevmeyi doğuracak olgulardan, nefret duygusu nefreti doğuracak olgulardan, göz ışıtan, kulak varlığıyla sesten haber vermesinden biliyoruz ki, duygular objelerinin varliklarından haber verirler.

-Duygunun yaratıcısı insan olamaz, çünkü insan yoktan yaratamadığı için objeye karşılık gelen bir duygu yaratamaz.

-O halde duyguların varliğını bildirdiği objeler vardır.

-ebediyet duygusunu tatmin edecek, var olmanın karşıllğ̆ minnet ve şükran duygularını iletebileceği bir varlık zorunludur

-O varlık Tanrı'dir.

$\mathrm{Bu}$ delili daha da genişletebilmek ve her bir maddesine "eğer bu kabul edilmezse..." şıklarını eklemek mümkündür. Ancak burada önemli olan ahlak delilinin başka türlü de ele alınabileceğini göstermektir.

\section{Sonuç}

Bütün ahlak felsefeleri gibi Kant'ın ahlak felsefesi de insan için, doğruya sevk edici kurallar koymak amacındadır. Bu kuralların başlangıç noktası insanın ahlaki varlık olduğu ve 
anlama yetisinin duyular dünyasının kanunların içerdiği ön kabulleridir. Kant'a göre insanın bizzat kendisi iyi veya kötü değildir. İyi veya kötü olan eyleme sebep olan maksimdir. Bu maksimin ahlakilik şartları, evrensel kanun olacakmış gibi eylemde bulunmak ile insanı amaç görmek şartlarıdır. Bilgi gibi ahlakın da apriori kökleri vardır ve bunlar evrenseldir. Maksimin ahlaklı olabilmesi için bu apriori ahlak kurallarına göre ve sırf ona uygun yapılması kastıyla eylemde bulunulmalı, yani hiçbir koşulluk bulunmamalıdır. Bu koşulsuz emir, kategorik imperatif, yani kesin emirdir. Koşulsuz kesin emirlere ihtiyarımızla uymak için özgürlüğümüz vardır. Özgürlük bir postulattır. Ahlakilik bu kesin emre uymaktır. Kesin emre uymak bir ödevdir. Sırf ödevden dolayı eylemde bulunulmalıdır. Ödev kavramı bize en üstün iyi'den haber verir. En üstün iyiye uymak bir erdemdir ve mutluluğa layık olmaktır. Halbuki insanın erdem ve mutluluğu bir araya getirmeye gücü yetmez. Çare ruhun ölümsüzlüğü ve Tanrı postulatlarıdır.

Kant'ın ahlak felsefesindeki çelişkilerden bazıları daha önce gösterilmiştir. Genel olarak Kant'ın ahlak felsefesindeki çelişkiler şunlardır;

Kant ahlak felsefesini akıl ile temellendirmek istediği ve onunla başladığı halde Tanrı postulatını koymak zorunda kalmıştır. Tanrı'nın mahiyeti meçhuldür. Üstün iyiyi gerçekleştirebilecek olması onun aktif olmasını gerektirdiği halde, Kant'ın Tanrısı Hıristiyanlıkta olduğu gibi pasiftir. Tanrının kabulü vahyin imkanını da gündeme getirdiği halde, Kant teolojik ahlaka karşı çıkmıştır. Kant insanı sırf bir akıl varlığı gibi düşünerek ahlak felsefesini kurmuş, aklın emrine uyulmadığı durumların da akla ters olmadığını nazara almamıştır. İnsanı fenomen ve numen olarak ikiye ayırarak ahlaka zemin hazırlamış, fakat insanın sırf numen tarafi nazara alınarak ahlak düşüncesi oluşturulmuştur.

Kant hem ahlaki değerleri insanın koyduğunu, hem de ahlak prensiplerinin evrensel olduğunu savunmak gibi bir duruma düşmüştür, çelişki'den kurtulmak için de Tanrı'yı kabul etmiştir. İnsana dayandırılan bir fikrin, insan duygularından sıyrılamadığı için sübjektif kalacağını nazara almamıştır. Kesin buyruklara uymak ile ahlaklı olunabileceğini savunmuş, fakat mutluluk gibi bir koşulluluk göz ardı edilememiştir. Eylemlerin ahlakiliğini sonuçlarına göre değil, onu işleten maksime, iyi istence göre değerlendirmiş, ne sonucun ne de niyetin her zaman ahlakilik ölçütü olamayacağını görememiştir. Ahlak felsefesi insanı ümitsizliğe düşürdüğü için Tanrı'yı kabul etmiş, arzu ve ihtiyaçtan Tanrı'nın varlığına gittiği ithamına maruz kalmıştır. Kant seküler dili kullanan bir teolog durumundadır. Kant takipçisi sayılabilecek filozoflardan özellikle Hegel'in Hıristiyanlığı akli temellere oturtmak için kurduğu sistemin arkasında Kant'ın Hıristiyanlıktaki gibi pasif tanrı anlayışı ve "numen"in içerdiği kavramların tarihteki pratik etkilerini akılla çözümleme vardir.

Ahlak felsefesi pratik anlamda insana emreden bir felsefedir. Dolayısıyla ahlak felsefesinde insanın farklı bir varlık olduğu ön kabulü vardır. Bu ön kabulü temellendirebilmek de mümkündür. İnsan ile aynı dünyada yaşayan varlıkların hiçbiri iyi-kötü, doğru-yanlış tespiti gibi bir gaye gütmediklerine göre, insan şüphesiz eti ve kemiği ile, duyguları ile ait olduğu alemden fazla şeyler ihtiva etmektedir. Bu farklı olan şeyler, hem onun aklı varlığı olmasından, hem de bulunduğu zamanın dışında da elem veya lezzet şeklinde istifade edebilmesinden ibaret özelliklerdir. İnsan bütünüyle hazır zamana ait bir varlık değildir. Onu bulunduğu zaman ile irtibatlandıran cismani duygularıdır. Bulunduğu zamanın dışına çıkartan da başta aklı olmak üzere ruhi yetenekleridir. İnsan için saadet her iki tür duygunun da tatminindedir. Ancak insandaki en kuvvetli duygu yok olmama duygusudur. Bu duygunun sevk etmesiyle araştırır, çözümler bulmayı dener. Varlığından ayrılmak tehlikesini ortadan kaldıracak ipuçları arar. Bu ipuçlara uygun eylemde bulunmak, varlığını koruma duygusunun sevk etmesindendir. Dolayısıyla doğru ve yanlışta ölçü, insanın 
sonsuzluk arzusuna uygun olup olmaması noktasındadır. Sonsuzluk kabul edilmediği zaman da, hazır zamanın menfaatine uygun olup olmama noktasındadır. Aklın sınırlı olduğunu Kant da kabul etmektedir. Öyleyse, insanın görevi sınırlı akıl ile emreden teoriler üretmek değil evrenin ve insanın ne olduğunu araştırmaktır. Çünkü, evrenin ve insanın mahiyeti bilinmeden söylenebilecek sözlerin isabetli olamayacağı aşikardır. Akıl otorite koyan değil, otoriteyi tespit edendir. Keşfedendir, icat eden değildir.

\section{Kaynakça}

Arslan, A. (1994): Felsefeye Giriş, Vadi Yayınları.

Aydın, M. (1987): Din felsefesi, Dokuz Eylül Üniversitesi Yayını.

Aydın, M. (1991): Tanrı-Ahlak ilişkisi, Diyanet Vakfi Yayını.

Bolay, S. H. (1996): Felsefi Doktrinler ve Terimler Sözlüğü, Akçağ Yay.

Cevizci, A. (1996): Felsefe Sözlüğü, Ekin Yayınları.

Elmas, M. F. (2015), "Kant'ta Pratik Aklın Eleştirisi Merkezinde "Tanrı" ve "Ruhun Ölümsüzlügü̈” Mavi Atlas Dergisi, 5/2015, 103-114

Gökberk, M. (1979): Felsefenin Evrimi, Milli Eğitim Basımevi.

Heimsoeth, H. (1986): Immanuel Kant'ın Felsefesi, (Çev. Takiyyeddin Mengüşoğlu),Remzi Kitabevi.

Janet, P.G. S. (1978): Metalib ve Mezahib, (Çev: Hamdi Yazır), Eser Neşriyat.

Kant, I. (1995): Ahlak Metafiziğinin Temellendirilmesi, (Çev: Ionna Kuçuradi), Türkiye Felsefe Kurumu.

Kant, I. (1994): Pratik Usun Eleştirisi, (Çev: İsmet Zeki Eyüboğlu), Say Yayınları.

Kant, I. (1960): Religion Within The Limits of Reason Alone, Harper and Row Publishers.

Kılıç, R. (1992): Ahlakın Dini Temeli, Diyanet Vakfı Yayını.

Kılıç, R. (1993) “Ahlakı Temellendirme Problemi”, Felsefe Dünyası Dergisi, Türk Felsefe Derneği Yayını.

Reichenbach, H. (1993): Bilimsel Felsefenin Doğuşu (Çev: Cemal Yıldırım), Remzi Kitabevi.

Uludağ, G. (2019). "Örgütsel Bağlllık İle İşten Ayrılma Niyeti İlişkisini İncelemeye Yönelik Bir Alan Araştırması", Atatürk Üniversitesi Sosyal Bilimler Enstitüsü Dergisi, 23(4) (Özel Say1), 2043-2056. 